\title{
Erratum to: Estimates of phenotypic and genetic parameters for birth weight of Brown Swiss calves in Turkey using an animal model
}

\author{
A. Sahin - Z. Ulutas • A. Yilmaz Adkinson • \\ R. W. Adkinson
}

Accepted: 8 June 2012 / Published online: 6 July 2012

(C) Springer Science+Business Media B.V. 2012

Erratum: $10.1007 / \mathrm{s} 11250-011-0036-6$

This erratum is published due to discrepancies in the equations.

The lines in last para of first partition in Page No. 1029;

Total heritability $\left(\mathrm{h}_{\mathrm{d}}{ }^{2}\right)$ was calculated using the following equation (Willham, 1980).

$\mathrm{h}_{\mathrm{d}}^{2}=\left(\sigma_{\mathrm{a}}^{2}+0.5 \sigma_{\mathrm{m}}^{2}+1.5 \sigma_{\mathrm{am}}\right) / \sigma_{\mathrm{a}}^{2}$.

has to be corrected as

Total heritability $\left(\mathrm{h}_{\mathrm{t}}^{2}\right)$ was calculated using the following equation (Willham, 1980).

$\mathrm{h}_{\mathrm{t}}^{2}=\left(\sigma_{\mathrm{a}}^{2}+0.5 \sigma_{\mathrm{m}}^{2}+1.5 \sigma_{\mathrm{am}}\right) / \sigma_{\mathrm{p}}^{2}$.

The online version of the original article can be found at http:// dx.doi.org/10.1007/s11250-011-0036-6.

A. Sahin $(\varangle) \cdot$ Z. Ulutas

Department of Animal Science, Faculty of Agriculture,

Gaziosmanpasa University,

60250, Tokat, Turkey

e-mail: aziz.sahin@gop.edu.tr

A. Y. Adkinson · R. W. Adkinson

Department of Animal Science, Faculty of Agriculture,

Erciyes University,

38039, Kayseri, Turkey 